\title{
Fault activity in the epicentral area of the 1580 Dover Strait (Pas-de-Calais) earthquake (northwestern Europe)
}

\author{
D. García-Moreno, ${ }^{1,2}$ K. Verbeeck, ${ }^{1}$ T. Camelbeeck, ${ }^{1}$ M. De Batist,${ }^{2}$ F. Oggioni, ${ }^{3}$ \\ O. Zurita Hurtado, ${ }^{2}$ W. Versteeg, ${ }^{2,4}$ H. Jomard, ${ }^{5}$ J. S. Collier, ${ }^{3}$ S. Gupta, ${ }^{3}$
} A. Trentesaux ${ }^{6}$ and $K$. Vanneste ${ }^{1}$

\author{
${ }^{1}$ Royal Observatory of Belgium, Av. Circulaire 3, 1180 Uccle, Brussels, Belgium. E-mail: David.GarciaMoreno@ugent.be \\ ${ }^{2}$ Renard Centre of Marine Geology, Ghent University. Krijgslaan 281 S.8, B-9000 Ghent, Belgium \\ ${ }^{3}$ Department of Earth Science and Engineering, Imperial College London. Prince Consort Road, London SW7 2BP, United Kingdom \\ ${ }^{4}$ Vlaams Instituut voor De Zee. InnovOcean site, Wandelaarkaai 7, B-8400 Oostende, Belgium \\ ${ }^{5}$ Institut de Radioprotection et de Sûreté Nucléaire. Av. de la Division Leclerc 31, Fontenay-aux-Roses, France \\ ${ }^{6}$ Université Lille 1, Lab. Géosystèmes UMR 8217 Lille1/CNRS, 59655 Villeneuve d'Ascq, France
}

Accepted 2015 January 20. Received 2015 January 19; in original form 2014 February 12

\begin{abstract}
SUMMAR Y
On 1580 April 6 one of the most destructive earthquakes of northwestern Europe took place in the Dover Strait (Pas de Calais). The epicentre of this seismic event, the magnitude of which is estimated to have been about 6.0, has been located in the offshore continuation of the North Artois shear zone, a major Variscan tectonic structure that traverses the Dover Strait. The location of this and two other moderate magnitude historical earthquakes in the Dover Strait suggests that the North Artois shear zone or some of its fault segments may be presently active. In order to investigate the possible fault activity in the epicentral area of the $\mathrm{AD} 1580$ earthquake, we have gathered a large set of bathymetric and seismic-reflection data covering the almost-entire width of the Dover Strait. These data have revealed a broad structural zone comprising several subparallel WNW-ESE trending faults and folds, some of them significantly offsetting the Cretaceous bedrock. The geophysical investigation has also shown some indication of possible Quaternary fault activity. However, this activity only appears to have affected the lowermost layers of the sediment infilling Middle Pleistocene palaeobasins. This indicates that, if these faults have been active since Middle Pleistocene, their slip rates must have been very low. Hence, the AD 1580 earthquake appears to be a very infrequent event in the Dover Strait, representing a good example of the moderate magnitude earthquakes that sometimes occur in plate interiors on faults with unknown historical seismicity.
\end{abstract}

Key words: Palaeoseismology; Intraplate processes; Submarine tectonics; Neotectonics; Europe.

\section{INTRODUCTION}

Assessing the seismic hazard associated with plate-interior tectonic structures is generally a very difficult task. For instance, the seismicity in these areas is generally too low to be studied by means of classic seismotectonic approaches. In addition, destructive earthquakes are rare and they usually appear randomly distributed in space and are sometimes located in places with no known historical seismicity (Zoback \& Grollimund 2001; Camelbeeck et al. 2007). This apparent randomness of the seismicity might be the consequence of recurrence intervals too long to have produced two significant ruptures of the same feature in historical times (Stein \& Mazzotti 2007). It is thus necessary to adopt palaeoseismic methods in order to understand and characterise the activity of intraplate faults and hence the possible present-day seismic hazard related to them.

This study focuses on the poorly known offshore Sangatte Fault, which traverses the marine Dover Strait (Pas de Calais) from Sangatte (northeastern France) to Folkestone (southeastern England; Figs 1 and 2). This fault is part of the North Artois shear zone (Fig. 1) and it is believed to be the probable source of the magnitude $\sim 6.0$ earthquake that occurred offshore in AD 1580 (Camelbeeck et al. 2007). Historical information suggests that this earthquake produced damage equivalent to MSK intensity VIII in Calais and Dover and about VI in London, and it was felt as far as Köln (Germany) to the east and York (England) to the north (Neilson et al. 1984; Melville et al. 1996; Musson 2004). According to the empirical relationships of Wells \& Coppersmith (1994), the 
inferred magnitude of the AD 1580 earthquake would correspond to an average fault length of $10 \mathrm{~km}$ and to a slip of $0.25-0.30 \mathrm{~m}$. However, nothing is presently known about any active fault located in the Dover Strait.

Apart from the AD 1580 earthquake, the Sangatte fault has only been associated with two other seismic events of moderate magnitude. These are the $M_{\mathrm{S}} \sim 4.0$ historical earthquake that occurred in 1776 (Melville et al. 1996) and the $M_{\mathrm{w}} 4.0$ Folkestone earthquake of 2007 (Ottemöller et al. 2009). The hypocentre of the latter was instrumentally localized about $5 \pm 2 \mathrm{~km}$ below Folkestone (Ottemöller et al. 2009).

The presence of major infrastructures and the densely populated cities within the area of influence of an earthquake similar to the AD 1580 event make it very important to assess the nature of the Sangatte Fault and its tectonic activity over time. In order to do so, we have gathered a large set of seismic-reflection and bathymetric data from the epicentral area of this earthquake. In this paper, we will present and discuss the interpretation of these geophysical data, which resulted in the first high-resolution bathymetric map of the Dover Strait and provided a clear visualization of the main tectonic structures and their activity over time.

\section{TECTONIC AND GEOLOGICAL SET T INGS}

The North Artois shear zone is a complex fault-and-fold system defining the western part of the Variscan Midi-Eifel Thrust Front (Fig. 1), which separates the Ardenne Massif and Paris Basin to the south (hanging wall) from the London-Brabant Massif to the north (footwall). The present-day geometry of this fault zone results from several phases of post-Palaeozoic deformation that have induced different reactivations of structures inherited from the Variscan Orogeny (e.g. Chadwick et al. 1993; Van Vliet-Lanoë et al. 1998, 2002a,b; Mansy et al. 2003; Minguely et al. 2010). Since its formation, the North Artois shear zone has passed from the original compressional setting (Variscan Orogeny) through extension related to the opening of the Tethyan and Atlantic ocean basins during Jurassic and Cretaceous times, and again to compression during the tectonic inversion that started in the early Palaeogene epoch due to the Alpine Orogeny (Vandycke et al. 1988; Bergerat \& Vandycke 1994; Van Vliet-Lanoë et al. 2002a,b, 2004; Mansy et al. 2003; Minguely et al. 2010).

From an analysis of gravity data, Everaerts \& Mansy (2001) concluded that the major fault segments comprising the North Artois shear zone have lengths ranging from 15 to $40 \mathrm{~km}$ and are arranged as right-stepping en-echelon fault zones (Fig. 2). Based on their gravity map, Camelbeeck et al. (2007) distinguished five major faults: that is Marqueffles Fault, Ruitz Fault, Pernes Fault, Landrethun Fault and Sangatte Fault (see Fig. 2). Not only their activity, but the precise geometry of these faults is still poorly known. This is especially true for the mostly submarine Sangatte Fault, on which there has been no specific study published until now; despite the fact that it corresponds to the most likely geological structure capable of having generated the AD 1580 event (e.g. Camelbeeck et al. 2007).

The Quaternary activity of the North Artois shear zone is still debated, as no conclusive field evidence of recent tectonic deformation has yet been associated with any of its fault segments. Indirect evidence includes possible extensional faults identified in the Sangatte cliff (Van Vliet-Lanoë et al. 2000) and minor right-lateral deformations affecting river development and Quaternary fluvial and aeolian deposits in northeastern France (Colbeaux et al. 1981;

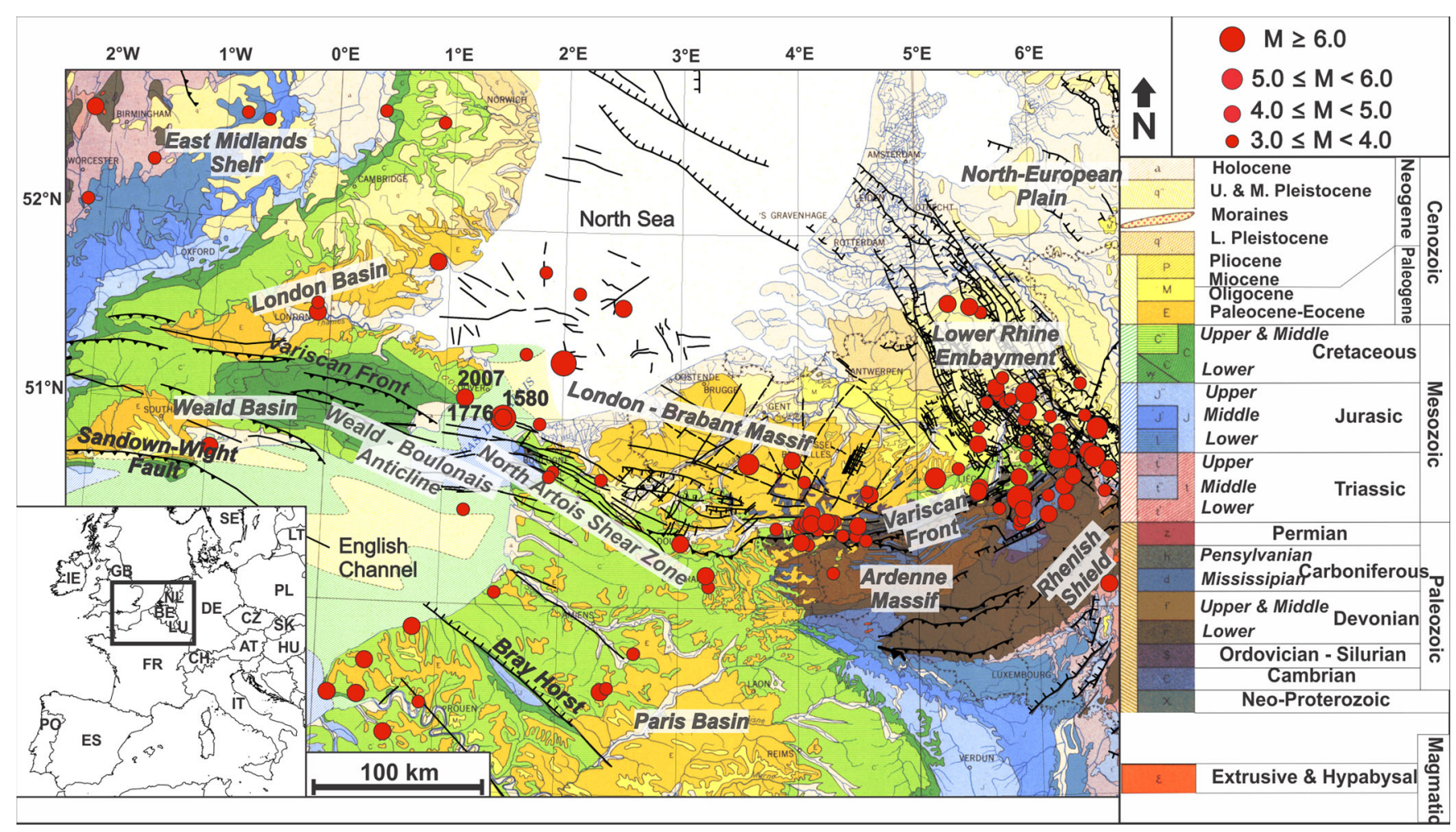

Figure 1. Onshore geological map of northwestern Europe updated with the geology of the English Channel and major tectonic structures (De Béthune \& Bouckaert 1968). Known historical and instrumental earthquakes $\left(M_{\mathrm{W}} \geq 3\right)$ are indicated scaled by magnitude according to catalogues from the Royal Observatory of Belgium and Grünthal et al. (2009). 


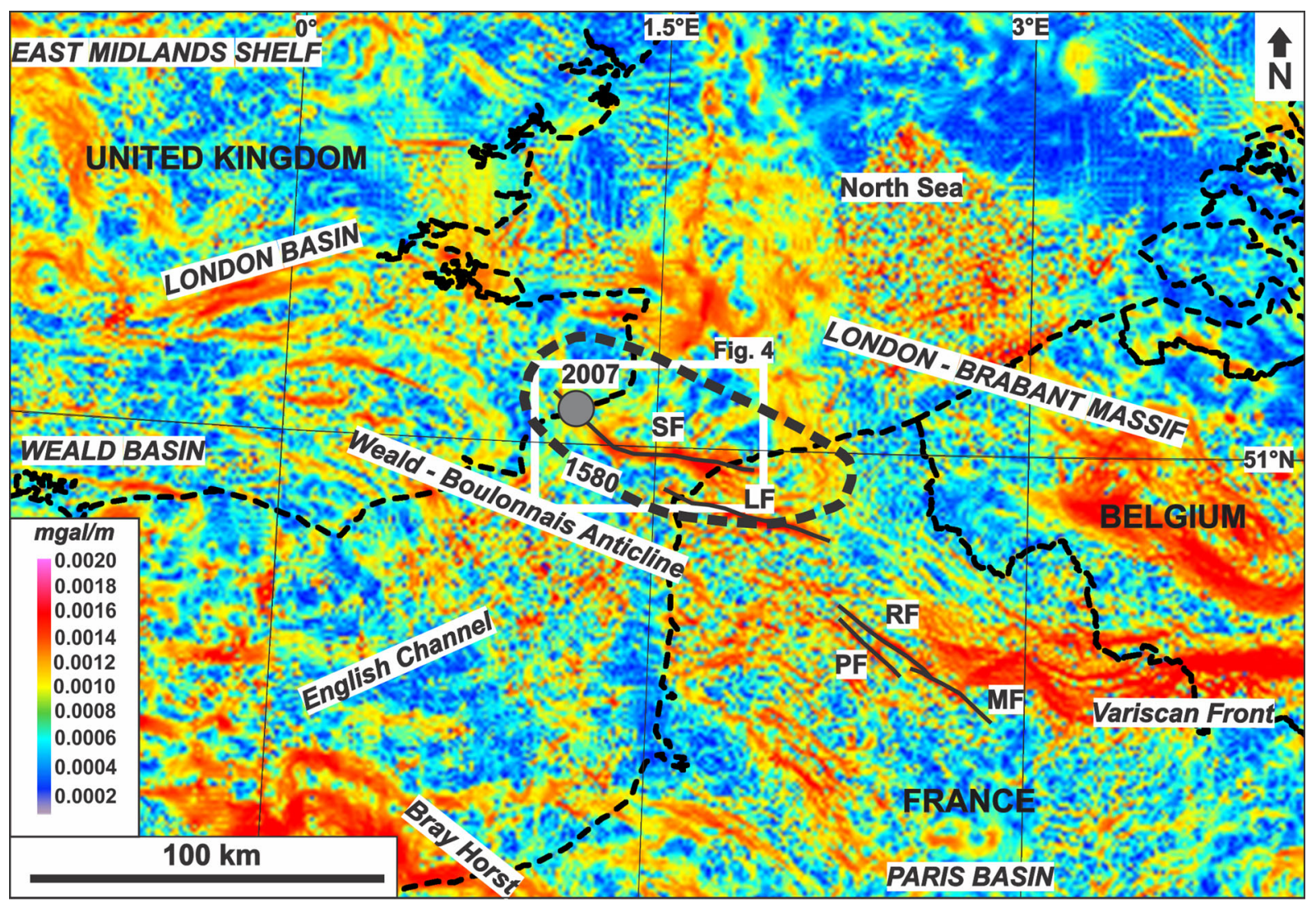

Figure 2. Interpreted horizontal derivative of the Bouguer gravity anomaly (see Everaerts \& Mansy 2001; Camelbeeck et al. 2007). The Bouguer anomaly was calculated using the gravity database of the Royal Observatory of Belgium. For France and United Kingdom the data were provided by the French and British Geological Surveys respectively. All gravity data are referenced to the gravity datum Uccle (1976) (IGSN71-0.048mGal). The density reduction used for the calculation of the Bouguer anomaly on land was 2.67. Above the sea, the free-air anomaly was used. Grey coloured circle: epicentre of the 2007 Folkestone earthquake (Ottemöller et al. 2009); dashed ellipsoid: isoseismal indicating MSK Intensity VII-VIII during the 1580 earthquake (Melville et al. 1996); LF, Landrethun Fault; SF, Sangatte fault; RF, Ruitz fault; PF, Pernes fault and MF, Marqueffles fault.

Van Vliet-Lanoë et al. 2002a; Mansy et al. 2003). The latter suggest right-lateral strike-slip deformation, which is in good agreement with the NNW-SSE orientation of the maximum horizontal stress measured near Boulogne by Froidevaux et al. (1980). However, it disagrees with the direction of the deformation suggested by the focal mechanism calculated for the 2007 Folkestone earthquake (Ottemöller et al. 2009), which indicates a left-lateral rupture along a WNW-SES fault (see Ottemöller et al. 2009).

According to some authors, the Sangatte Fault may have been in active extension during the deposition of the Gault Clay and Lower Chalk formations in the Cretaceous (Warren \& Harris 1996; Ottemöller et al. 2009; Minguely et al. 2010). On the 1:250 000 offshore geological maps published in 1988 and 1989 by the British Geological Survey (BGS) and the compilation of geological data performed by James et al. (2002), the Sangatte Fault is represented as several WNW-ESE trending minor faults and folds traversing the Cretaceous bedrock (Fig. 3). This structure also traverses two significant Quaternary features situated in the centre of the Dover Strait (Figs 3 and 4): a broad palaeochannel known as the Lobourg Channel and a complex sediment-filled palaeobasin network known as the 'Fosse Dangeard' (see Destombes et al. 1975; James et al. 2002). Elsewhere Quaternary sedimentary features are mainly limited to a number of major (stable) and minor (mobile) Holocene sandbanks (Mellet et al. 2013) separated by areas with thin or absent sedimentary cover (see James et al. 2002). Recent tectonic movements affecting the latter features will not be preserved for long due to the dynamic conditions this area has been subjected to during the Holocene, with strong sediment reworking, erosion and sediment starvation (e.g. Hamblin et al. 1992). On the other hand, if the Sangatte Fault reaches the surface and has ruptured several times in earthquakes similar to the AD 1580 since the Fosse Dangeard and the Lobourg Channel were formed, the cumulated deformation produced on these erosional features should be measurable.

The Fosse Dangeard is a kilometre-scale network of sedimentfilled palaeobasins that are incised several tens of metres into bedrock (e.g. Destombes et al. 1975; Smith 1985; James et al. 2002). The origin of these buried palaeobasins is presently uncertain, although most authors agree that they were probably formed during the Middle Pleistocene. Initially, they were attributed to glacial processes (Destombes et al. 1975). Nevertheless, most of the recent studies seem to agree that none of the Pleistocene ice sheets extended that far south (e.g. Clark et al. 2004). Hamblin et al. (1992) thus proposed that the Fosse Dangeard may be the result of the combination of fluvial erosion and tidal scouring during, respectively, Pleistocene low and high sea level stands. Van Vliet-Lanoë et al. (2004) suggested a possible tectonic origin for these basins. However, considering the amount of deformation necessary to create such large basins, similar offsets should be observable in Quaternary deposits along the on-shore continuation of these structures, which is not the case (e.g. Minguely et al. 2010). A tectonic origin of the fosse is thus very unlikely. Presently, it is widely accepted that these palaeobasins have been originally carved into the bedrock 


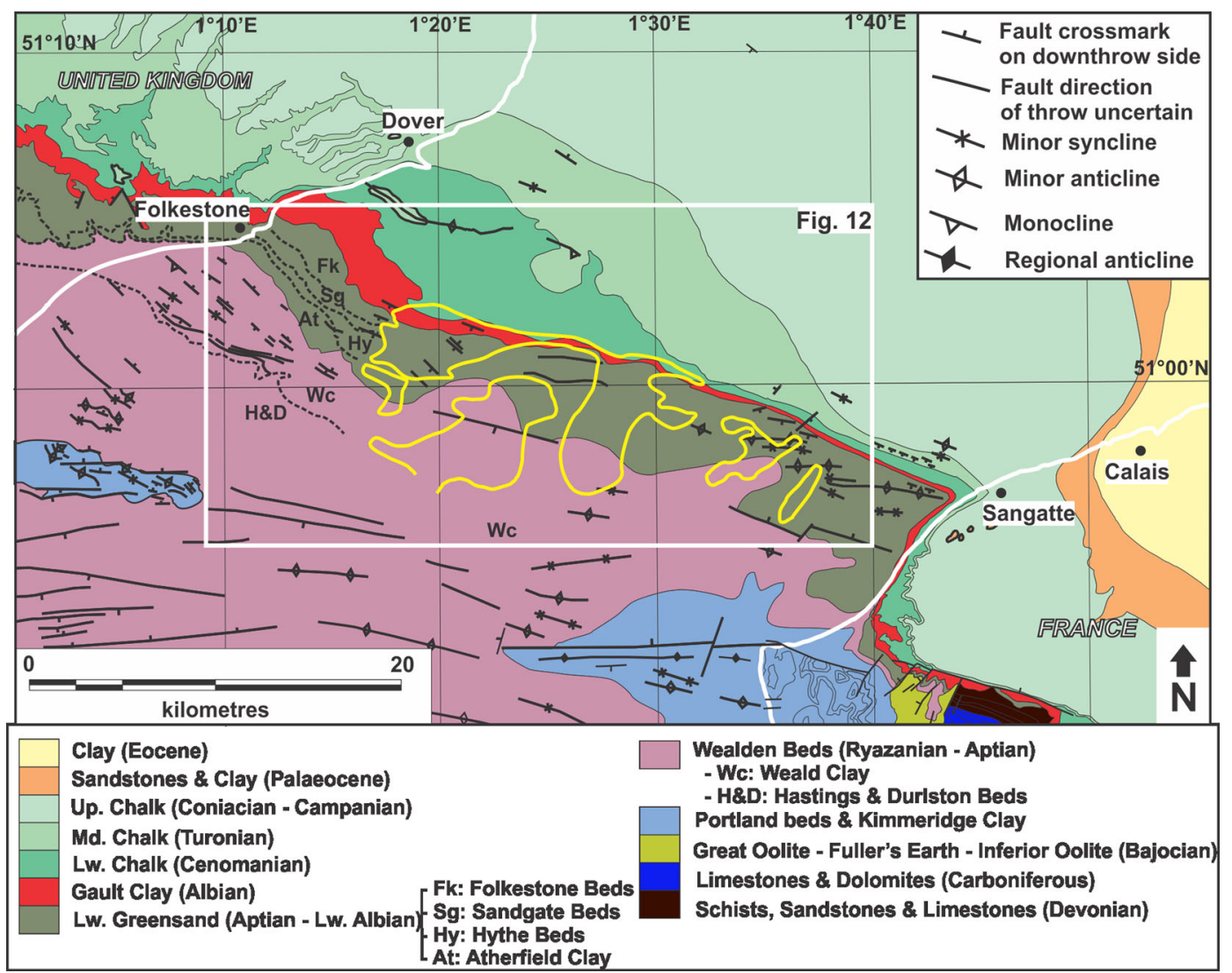

Figure 3. Bedrock geology of the Dover Strait/Pas-de-Calais area constrained by combining the 1:250 000 geological maps published by the BGS in 1988 and 1989 (sheets 51N00 and 50N00) and the maps published by James et al. (2002). White rectangle indicates the area shown in Fig. 12. The yellow line represents the location of the Fosse Dangeard according to James et al. (2002).

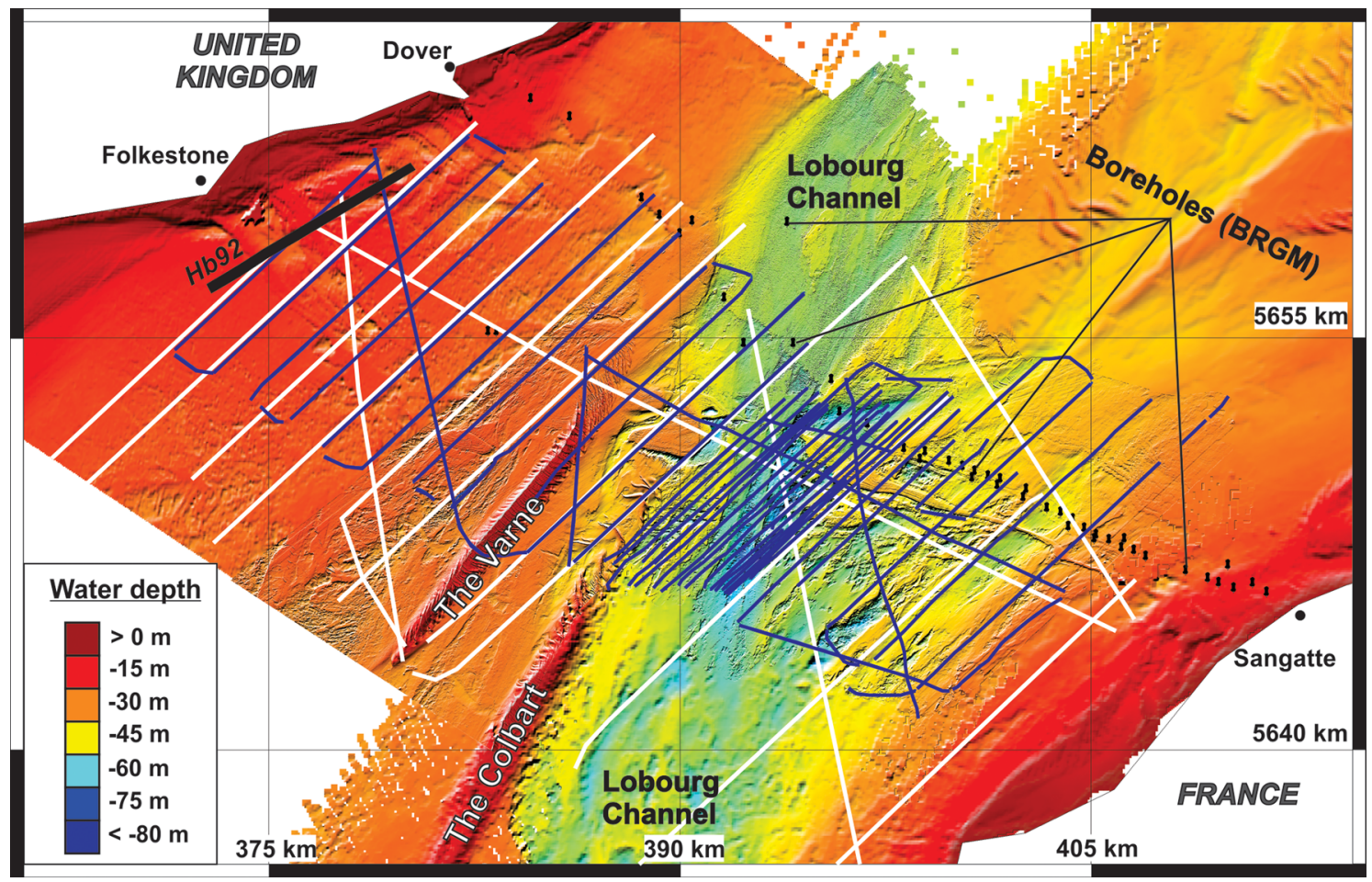

Figure 4. Merged bathymetry, single- (dark blue lines) and multichannel (white lines) seismic-reflection profiles gathered for this study, and boreholes archived at BRGM. Hb92: location of the single-channel seismic-reflection profile interpreted by Hamblin et al. (1992). Projection for this and following figures: UTM-31N (WSG84). 
by a mega-flood produced during the breaching of the Weald-Artois ridge, which used to separate the southern North Sea from the English Channel (Smith 1985; Gupta et al. 2007).

Dating of the Fosse Dangeard is currently limited to pollen extracted from a $50 \mathrm{~m}$ borehole collected from one of its sedimentfilled palaeobasins (Destombes et al. 1975). This dating suggests that these sediments were deposited during the Brørup interstadial of the Weichselian glaciation. Based on this dating, Destombes et al. (1975) argued that the Fosse Dangeard should have been formed in a previous stage, as the features themselves reach depths up to $100 \mathrm{~m}$. In addition, the sedimentary infill of these palaeobasins presents several erosional surfaces (Destombes et al. 1975), attesting to different phases of scouring and infilling. These authors thus proposed that the Fosse Dangeard was formed and firstly filled-up with sediments during the previous (Saalian) glaciation (0.35-0.13 $\mathrm{Ma}$ ). This feature may actually be much older, as considering the mega-flood hypothesis postulated by Smith (1985) and Gupta et al. (2007) its formation would be associated with the opening of the Dover Strait. The exact age of this event is presently unknown. However, it is generally accepted (e.g. Gibbard 1995; Toucanne et al. 2009) that it occurred during the Elsterian/Anglian glacial stage (0.48-0.40 Ma).

The Lobourg Channel is a broad NE-SW palaeochannel extending along the Dover Strait and cut predominantly into bedrock (James et al. 2002). This palaeochannel extends to the southwest into a complex anastomosing system of valleys that can be mapped continuously from a few kilometres northeastward of the Dover Strait to the western approaches (e.g. Smith 1985; Lericolais et al. 2003; Gupta et al. 2007). Presently, two main hypotheses are proposed to explain this major erosional feature. Some authors (e.g. Gibbard 1995; Lericolais et al. 2003) suggest that these palaeovalleys were part of an enormous palaeodrainage system (Channel/Manche River) that was fed by the North European rivers during the major Middle and Late Pleistocene marine low stands. Others authors have proposed that this feature may have been created by several episodes of Middle Pleistocene catastrophic flooding (e.g. Smith 1985; Gupta et al. 2007). In any case, both groups of authors agree that the Lobourg Channel formed following the breach of the Weald-Artois ridge. This palaeochannel was probably active during all the major Middle and Upper Pleistocene marine low stands, being finally submerged at the end of the last glaciationbeginning of the Holocene epoch (e.g. Gibbard 1995; Lericolais et al. 2003; Toucanne et al. 2009).

\section{METHODOLOGY AND AVAILABLE DATA}

This study is based on the interpretation of several sets of bathymetric and seismic-reflection data (Fig. 4) collected across the gravity anomaly observed by Everaerts \& Mansy (2001) traversing the Dover Strait (see Fig. 2). The principal seismic-reflection dataset comes from three geophysical campaigns organized by the Royal Observatory of Belgium (ROB) in collaboration with the Renard Centre of Marine Geology (RCMG) in 2010 and 2012 on board of RV Belgica (cruise reports 2010/09, 2012/03 and 2012/25 available from www.mumm.ac.be). These campaigns consisted of the acquisition of 17 multichannel (total 309 line $\mathrm{km}$ ) and 48 single-channel (total 487 line $\mathrm{km}$ ) seismic-reflection profiles over the entire width of the strait and more than $300 \mathrm{~km}^{2}$ of multibeam bathymetric data from its central part. These data were complemented with 20 other high-resolution seismic-reflection profiles acquired from the central part of the Dover Strait by the RCMG and Lille University in 2002 on board of RV Sepia II (Dangeard I Cruise), as well as with parts of two bathymetric datasets provided by Imperial College London.

The seismic dataset mainly consists of parallel lines. This was due to limitations of collecting lines across the Dover Strait due to strong tides and shipping lane restrictions. The high quality bathymetric data was therefore invaluable to correlate between the seismic profiles. Notably, the high resolution of this (horizontal resolution $1.5-5 \mathrm{~m}$ ) and the single-channel seismic-reflection (vertical resolution 1-3 m) datasets permitted the visualization of features as small as $1.5 \mathrm{~m}$ in the centre of the strait. Specific technical details on the vertical and horizontal resolutions of the geophysical data, as well as on their acquisition and processing, can be consulted in the electronic supplement attached to this paper.

\section{INTERPRETATION OF THE GEOPHYSICAL DATA}

\subsection{Seismic stratigraphic interpretation}

In this study, correlations between geology and seismic stratigraphy were first done in the northwesternmost seismic-reflection profile collected for this study and correlated afterwards southeastward from one profile to another. The interpretation of the first profile is based on the equivalence established by Hamblin et al. (1992) between geology and the seismic stratigraphy of one single-channel seismic-reflection profile acquired nearby the English shore (see location in Fig. 4). We complemented this interpretation with several interpreted boreholes (Fig. 4) stored at the BRGM (www.brgm.fr) and the available geological maps from the Dover Strait (Fig. 3). Correlations between seismic profiles were performed using the few available cross-lines and the merged bathymetry. The latter proved invaluable in correlating between the seismic profiles, as many of the sedimentary formations form distinct geomorphological features on the seafloor that can be followed along the entire width of the strait (see Figs 5, 6 and 8). The geological interpretation presented in this study is limited to the first $100 \mathrm{~m}$ below the seabed, as we were not able to completely remove the first seabed multiple in the multichannel seismic-reflection data. Hence, we have very little information on the structure below the Wealden Beds of Lower Cretaceous age (Fig. 7).

The strata imaged in the seismic-reflection profiles correspond to Lower and Upper Cretaceous sedimentary rocks and the sediments infilling Quaternary palaeobasins and palaeochannels or forming sandbanks. Palaeogene and Neogene units are missing in this area. The Quaternary palaeobasins and palaeochannels are the easiest features to identify in the seismic-reflection data due to the distinct unconformity formed by their basal erosional surfaces (BES). The seismic facies infilling the largest features (i.e. the Fosse Dangeard) comprise several subfacies composed of seismic reflections with low to moderate amplitude. These subfacies are separated (and truncated) by thin packages of high amplitude reflections that seems to correspond to erosional surfaces carved into the sedimentary infill (Fig. 9).

During this study, we mapped the various Quaternary deposits, constructing isopach maps along the different seismic-reflection profiles by subtracting the two-way times (TWT) of the BES and seabed and assuming a velocity of $1750 \mathrm{~m} \mathrm{~s}^{-1}$, as proposed by Arthur et al. (1997) from log tests performed for the Channel Tunnel geo-engineering investigations. We have included the isopach map 


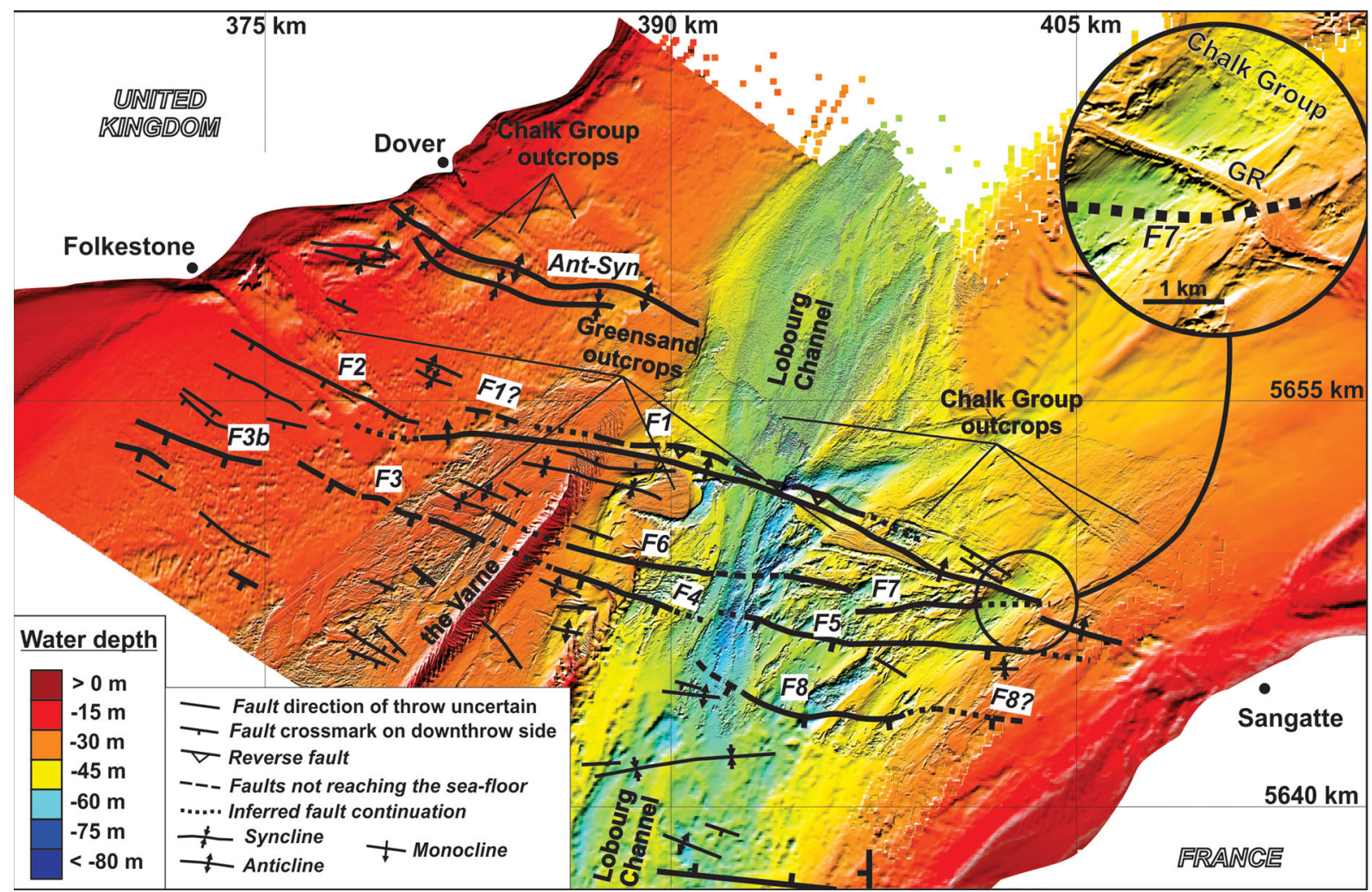

Figure 5. Structural map derived from the interpretation of the seismic reflection and multibeam bathymetric datasets collected for this study. Major bathymetric features are also indicated. Ant-Syn, Anticline/Syncline system. GR, Greensand Ridge.

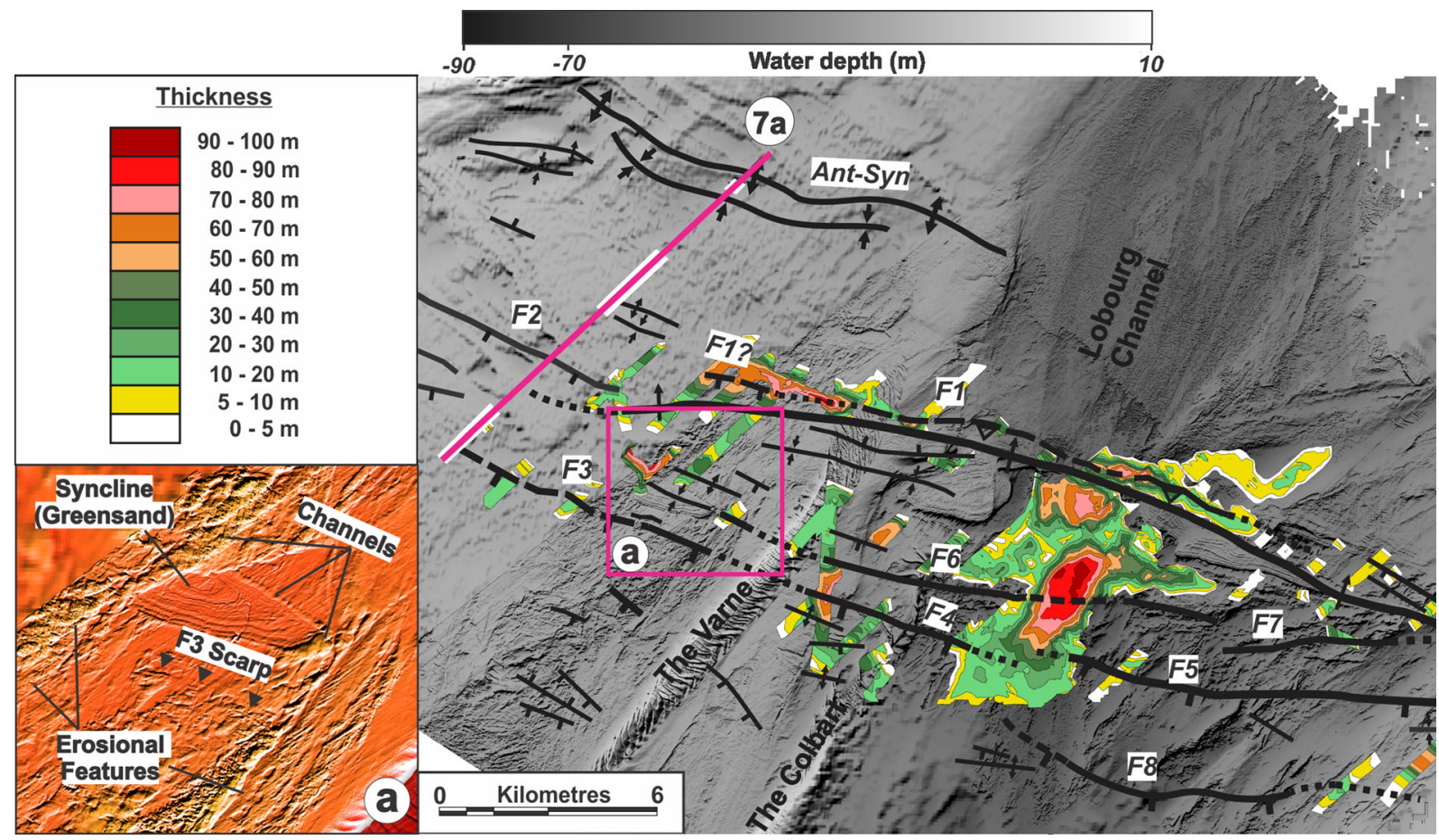

Figure 6. Structural interpretation and isopach map of the sediments infilling Quaternary palaeobasins and palaeochannels. (a) Enlarged view of the purple square indicated in the structural map. Location of the single-channel seismic-reflection profile shown in Fig. 7(a) is indicated. 


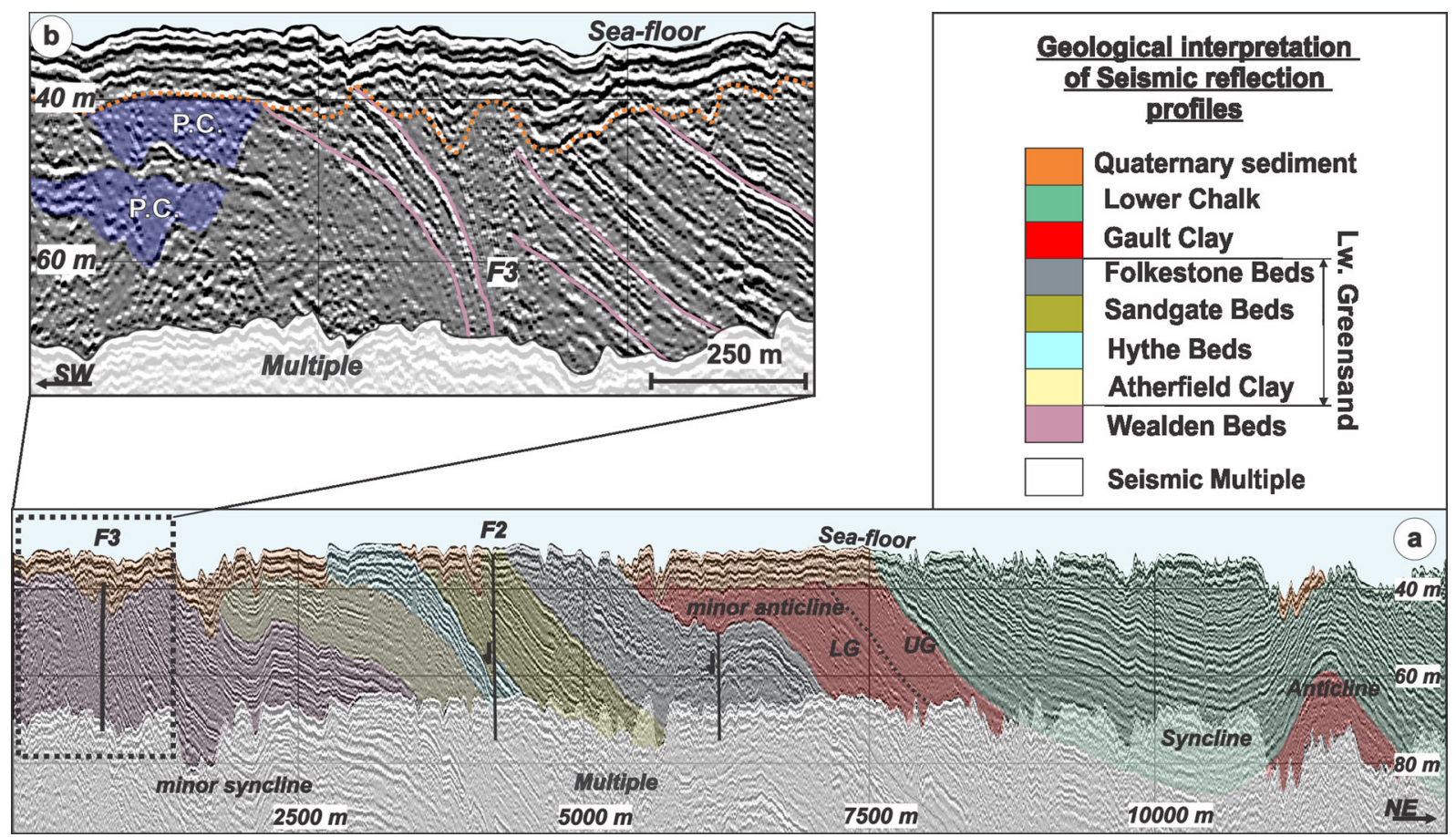

Figure 7. (a) Interpreted single-channel seismic-reflection profile (see Fig. 6 for location). (b) Enlarged view of the rectangle (dash outline) indicated in (a). P.C.: Wealden buried palaeochannels; pale violet lines in (b): seismic horizons selected to illustrate the strata geometry around F3. The depth conversion in this and the following interpreted seismic profiles is based on a mean constant velocity of $2000 \mathrm{~m} \mathrm{~s}^{-1}$.

in Fig. 6 to illustrate the distribution of the Quaternary deposits with regards to the main tectonic structures.

Concerning the seismic-stratigraphy of the Cretaceous bedrock, we identified the following seismic units, from Lower to Upper Cretaceous age:

(1) The upper part of the fluvial and lacustrine Wealden Beds (see Hamblin et al. 1992; Radley \& Allen 2012), which are characterised by a succession of well-defined low and high amplitude reflections in its upper part that become discontinuous and heterogeneous with depth. The seismic-reflection profiles show significant lateral variability of this unit's seismic facies, with the presence of buried palaeochannels and other erosional/depositional features consistent with its continental origin (Fig. 7b).

(2) The shallow marine/shoreline deposits known as the Lower Greensand (see Ruffell \& Wach 1991; Hamblin et al. 1992; Hopson et al. 2010), which are divided into four units in the eastern English Channel (e.g. Hamblin et al. 1992; Hopson et al. 2010); from old to young: Atherfield Clay, Hythe Beds, Sandgate Beds and Folkestone Beds. The Atherfield Clay presents an almost completely acoustically transparent facies (Fig. 7a). The Hythe Beds appear as a package of reflections of moderate amplitude. The Sandgate Beds consist of seismic subunits composed of reflections of moderate amplitude alternating with seismic subunits comprising reflections with relatively lower amplitudes (Fig. 7a). Finally, the Folkestone Beds are characterised by very diffuse and wavy reflections presenting hyperbolic diffractions (Fig. 7a). In general, the Lower Greensand formation thins to the southeast. This is especially true for the upper part of the sequence, with the Sandgate Beds thinning by as much as 25 per cent and the Folkestone Beds being no longer recognizable in the southeastern half of the strait (Fig. 8). Assuming that the Folkestone Beds are absent in the southeast (see next point), the Lower Greensand formation is $\sim 30 \mathrm{~m}$ thicker offshore England than offshore France (compare Figs 7 and 8).
(3) The marine deposits known as Gault Clay (see Hamblin et al. 1992; Hopson et al. 2010) present two distinct parts. The upper half of this formation is acoustically almost transparent, whereas the lower one has a more heterogeneous acoustic character with the appearance of low amplitude reflections (Fig. 7). We believe that these two subunits are equivalent to the Upper and Lower Gault Clay described by Owen (1975) and Woods et al. (1995). This subdivision is clearly observed near the British coast. However, it becomes more ambiguous towards France, where a seismic unit showing very similar characteristics to the lower Gault Clay lies directly on top of a seismic unit resembling the Sandgate Beds (Figs 8 and 9). The Folkestone Beds appear thus to be missing in that area.

The thickness of the Gault Clay formation ranges between 30 and $50 \mathrm{~m}$ across the survey area, generally getting thinner to the southeast. This is consistent with its outcrop in northern France, where only $11 \mathrm{~m}$ of this unit are recorded (e.g. Hamblin et al. 1992).

(4) Finally, the marine Chalk Group, which is generally subdivided in three units (Hamblin et al. 1992; Mortimore 2011), i.e. the Lower, Middle and Upper Chalk formations. The Lower Chalk formation is especially easy to identify in the seismic-reflection profiles thanks to the double diffraction produced by the Channel Tunnel (Fig. 8), which was bored into it (Warren \& Harris 1996). Moreover, the lower boundary of the Lower Chalk formation is highlighted by the contrast between the reflections of moderate amplitude characterising its seismic facies and the almost acoustically transparent Upper Gault Clay that lies underneath (Fig. 7a). The boundaries between the three Chalk formations themselves are much less evident because their seismic facies vary significantly from one profile to another. In this study, we have therefore mapped these boundaries by combining our seismic-reflection and bathymetric datasets with the BRGM borehole descriptions and the bedrock-geological map shown in Fig. 3. 


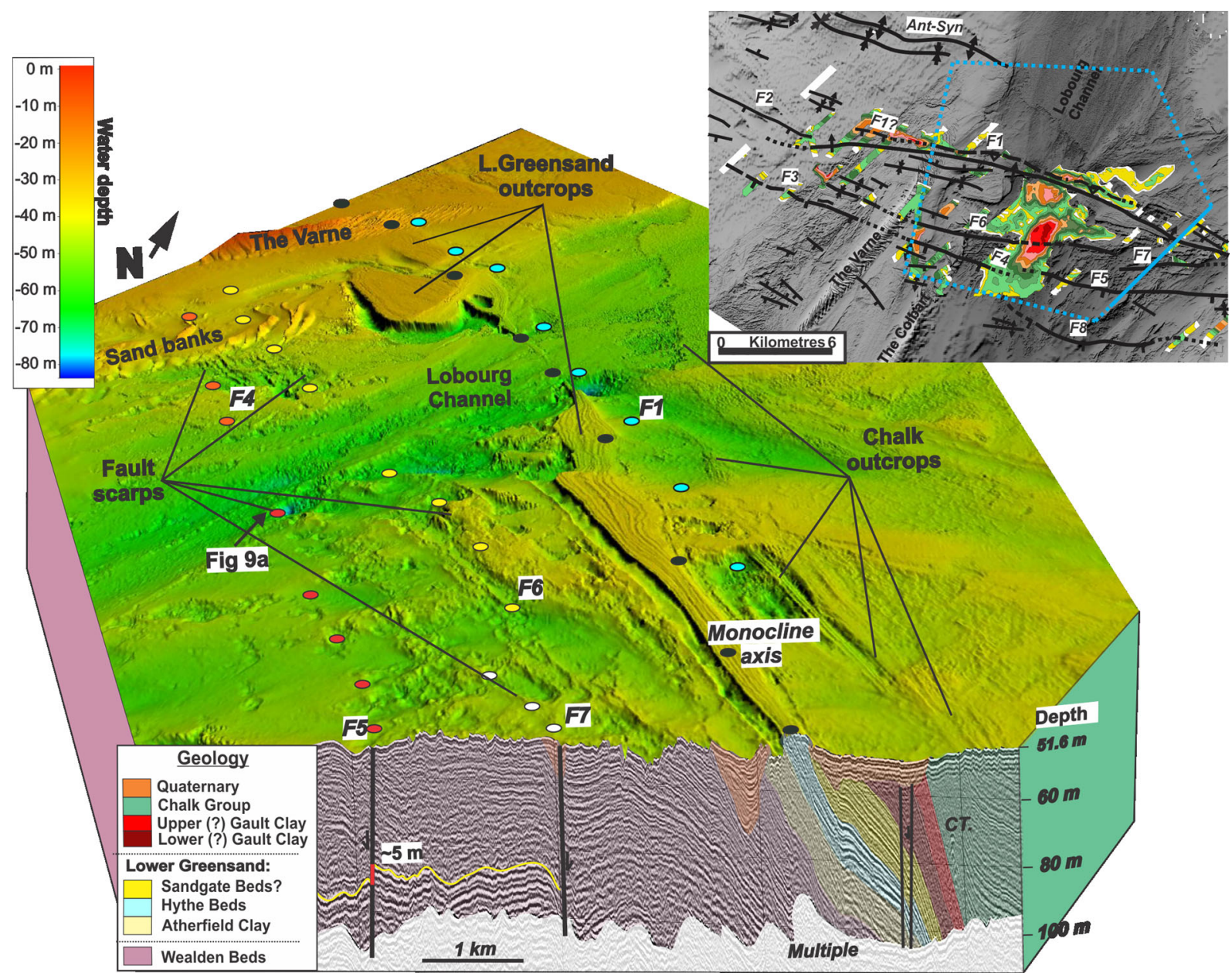

Figure 8. 3-D block showing the central and southeastern merged bathymetry in relationship with the interpretation of one of the single-channel seismicreflection profiles. Coloured circles in the bathymetry represent the fault traces and monocline axis inferred from the seismic investigation. CT: hyperbolic diffraction due to the Channel tunnel; Fig. 9a: location of the fault scarp shown in Fig. 9 (a). Inset: structural map with the area shown in the 3-D block (dash line) indicated. Blue line: location of the seismic-reflection profile. See Fig. 6 for the Inset depth colour scale, isopach map shade scale and structural interpretation.

All of the sedimentary formations described above outcrop at the seafloor, where they define several subparallel WNW-ESE ridges and sharp slopes resulting from differential erosion (Figs 5, 6 and 8). Especially marked in the bathymetry are some of the units composing the Lower Greensand and Chalk Groups, which withstand erosion better than the Gault Clay and Wealden Beds formations. For instance, the Hythe Beds form a prominent ridge (in this paper referred to as Greensand ridge) on the seafloor that can be followed over almost the entire width of the Dover Strait (see Figs 8 and 9). The different response to erosion of the Cretaceous sedimentary formations outcropping at the seafloor has also emphasized some old tectonic-related features, like minor folds and fault scarps (Figs 6a and 8). In addition to the outcropping bedrock, the seafloor presents two prominent Quaternary erosional/sedimentary features: the aforementioned broad NE-SW palaeochannel, known as the Lobourg Channel, and two kilometre-scale, elongated, subparallel sandbanks, called The Varne and The Colbart (Fig. 4). The latter two are associated with postglacial Holocene sea level rise (Reynaud et al. 2003; Mellet et al. 2013). In addition to these major sedimentary/erosional features, the bathymetry shows several minor Quaternary sandbanks and erosional features (troughs, grooves, channels, etc.) carved in the seafloor over the entire study area (see Figs 5, 6 and 8).

\subsection{Tectonic interpretation}

The geometry of the Cretaceous strata outcropping in the Dover Strait is strongly controlled by several WNW-ESE subparallel minor and major synclines, anticlines and fault systems (Figs 5-12). We can distinguish two deformation styles: (1) a broad asymmetric anticline/syncline system, a north-facing monocline structure and a reverse fault (F1), all three accommodating apparent compressional deformation; and (2) several faults accommodating vertical offsets more typical of extensional or strike-slip settings.

The north-facing monocline structure traverses the almost-entire width of the Dover Strait with its axis coinciding on the seafloor with the ESE-WNW striking Greensand ridge (Fig. 8). This structure is without doubt the most significant deformational feature located in the Dover Strait, in which the otherwise subhorizontal Cretaceous strata are significantly tilted to the east (Fig. 8). The monocline structure accommodates most of the deformation documented by the seismic investigation. In fact, the vertical offset produced by this structure is obscured in the seismic-reflection profiles by the first seismic multiple. This means that it must be larger than the maximum vertical penetration of the single-channel seismicreflection data. We can thus assume offsets greater than $100 \mathrm{~m}$ (see Fig. 8). 


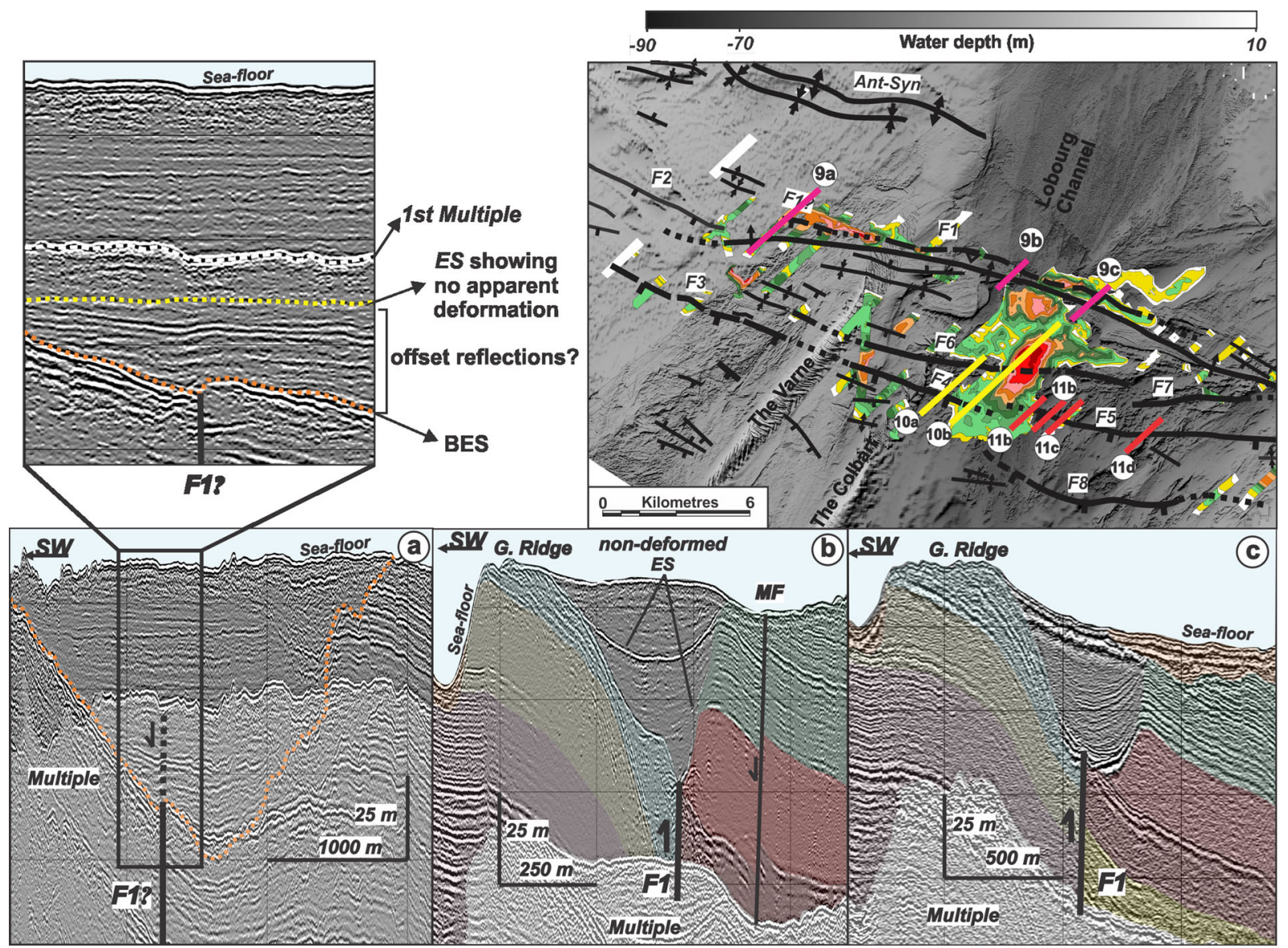

Figure 9. Selected parts of three single-channel seismic-reflection profiles (dark pink lines in structural map) acquired across fault F1. G. Ridge, Greensand ridge; BES, basal erosional surface; ES, erosional surface; MF, minor fault (only identified in this profile). See Figs 6 and 7 for isopach map shade scale and geological interpretation of the seismic-reflection profiles, respectively. Yellow and red lines in the structural map indicate the location of the seismic-reflection profiles shown in Figs 10(a) \& (b) and 11(a)-(d).

F1 is located in the central part of the strait, running parallel to the monocline structure over more than $13 \mathrm{~km}$ (Figs 5 and 6). This high-angle $\left(60-80^{\circ}\right)$ west-dipping fault juxtaposes the Gault Clay and Lower Chalk formations against the lower units of the Lower Greensand (Figs 9b and c), suggesting significant reverse offsets. This fault rarely reaches the seafloor due to the presence of a sediment-filled palaeobasin carved along its almost-entire length (Fig. 9). The presence of this palaeobasin and the high position of the seismic multiple prevented the direct measurement of the vertical offset induced in the Cretaceous bedrock by this structure. A rough estimation of $40-50 \mathrm{~m}$ can be calculated though assuming that the thickness of the Lower Greensand formation does not vary too much between the seismic-reflection profiles shown in Figs 8 and 9 (c) (distance $\sim 5 \mathrm{~km}$ ).

F1 seems to terminate to the northwest at one of the Fosse Dangeard palaeobasins (Fig. 9a). At that location, the BES and lower internal strata of this palaeobasin are $\sim 5 \mathrm{~m}$ offset to the southwest (Fig. 9a). This suggests normal or strike-slip faulting instead of the reverse deformation observed along F1 farther to the southeast (Fig. 9c). This might indicate, on the one hand, that F1 accommodated some normal or/and strike-slip deformation following the formation of the Fosse Dangeard. On the other hand, it is also possible that we are looking at two different faults presenting opposite deformational style. In any case, the offset disappears above the first erosional surface that truncates the lower layers of the palaeobasin infill (Fig. 9a). Other troughs and small buried scarps are seen farther to the southeast at the intersection of the Quaternary palaeobasin and F1 (Figs 9b and c). These features are also limited to the BES and lowermost strata infilling the palaeobasin and do not show any predominant deformation style.

Finally, the anticline/syncline system is located $\sim 6 \mathrm{~km}$ to the northeast of the monocline/F1 structure presenting a similar trend and lateral extent as F1 (see Figs 5-7). Besides some minor nondeformed Quaternary palaeochannels carved into this structure, deposits younger than Upper Cretaceous have been eroded or not deposited on top of it, preventing the assessment of the complete activity history of this feature.

The second set of tectonic structures, that is those accommodating apparent extensional and/or strike-slip deformations, is composed of several minor and major high-angle $\left(60-90^{\circ}\right)$ - fault systems. The most significant are: the WNW-ESE trending faults F3 and F4 and the W-E trending faults F5, F6, F7 and F8 (see Figs 5-12). Faults F3, F4 and F5 show similar geometries and characteristics, which suggests that they are probably different segments of the same system. All three faults dip to the southwest and offset normally the Wealden Beds. The offsets produced by these faults vary both laterally and with depth, ranging between 5 and $40 \mathrm{~m}$. This is well evidenced in Fig. 11, where we observed an increase of the offset from northwest to southeast from $\sim 9$ to $\sim 24 \mathrm{~m}$ in less than $2 \mathrm{~km}$ along strike. The offset decreases again to $\sim 5 \mathrm{~m} 3.5 \mathrm{~km}$ further to the southeast (Fig. 11d). We have also noticed that the Wealden strata located to the southwest (hanging wall) of F5 is generally 


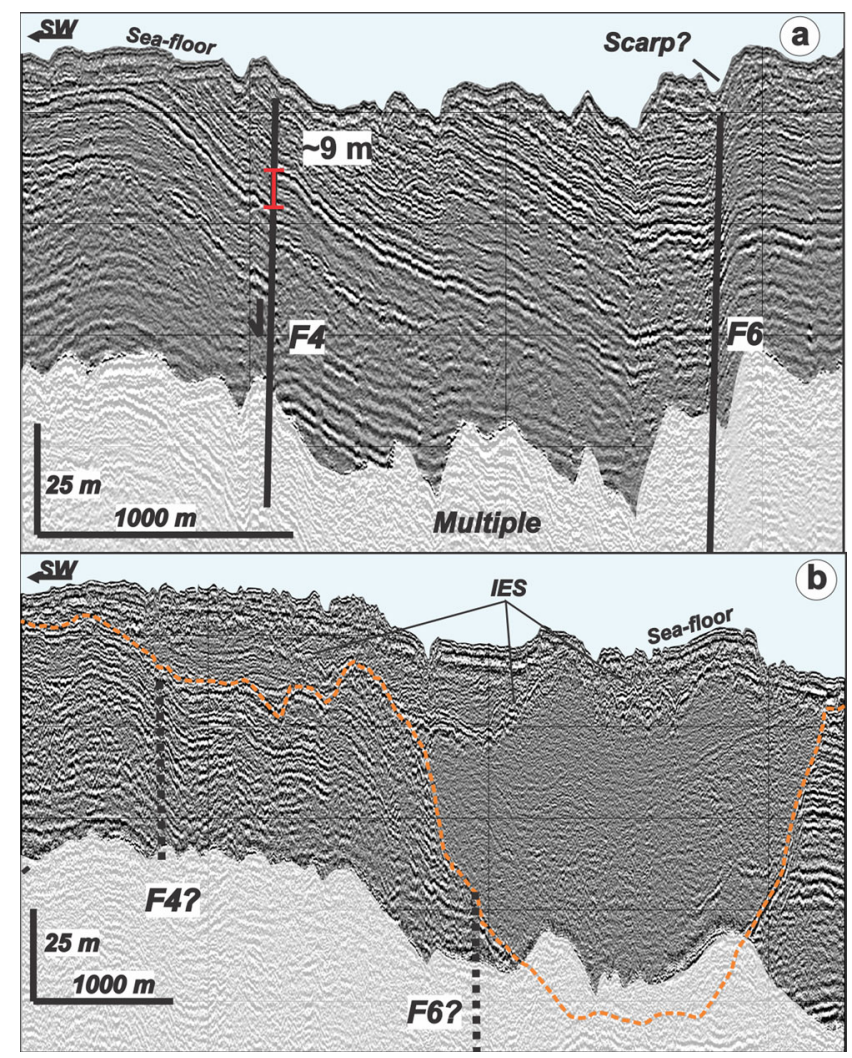

Figure 10. Parts of two single-channel seismic-reflection profiles (location indicated in Fig. 9) traversing faults F4 and F6, and a major palaeobasin of the Fosse Dangeard. Orange dashed line in (b): palaeobasin BES.

downwarped near the fault plane (Fig. 11). This downward bending of the strata varies significantly along strike and with depth, being sometimes more pronounced in the upper seismic units than in the lower ones (Fig. 11b).

The fault system F3-F4-F5 presents minor scarps in the outcropping Wealden Beds (Fig. 6a). However, it does not seem to reach the seabed surface through the Quaternary sediment-filled palaeobasins and palaeochannels. Rather, the possible Quaternary deformations accommodated by these faults are limited to the BES and lowermost infill of the palaeobasins (see Figs 7b and 10b). Only F5 seems to extend locally all the way to the seafloor along the western slope of a partially filled depression carved into the Lobourg Channel (Figs 8 and 11a). Nevertheless, despite the clear throws observed at depth in seismic-reflection profiles acquired less than $200 \mathrm{~m}$ apart, the scarp associated with F5 is restricted to the partially filled depression (Figs 8 and 11). No other scarp or offset have been observed within the Lobourg Channel or any of the other sediment-filled palaeobasins traversed by this fault system (see Figs 7b, 10b and 11). In fact, the deformation possibly linked to the tectonic activity of the system F3-F4-F5 at other locations consists of small changes in the geometry of the palaeobasin's BES and lower infill near to or across the fault planes (e.g. Fig. 7b). This suggests that F5 was exhumed at that location by a concentration of the scouring rather than by fault activity.

Faults F6 and F7 are both high angle E-W trending faults separated by a right step-over of $1.4 \mathrm{~km}$ (Fig. 5). These faults present localized minor scarps on the seafloor within outcropping Wealden Beds and in locations with thin Quaternary sedimentary cover (Fig. 8). The scarps are not continuous through the Lobourg Channel, where the erosional/depositional features located
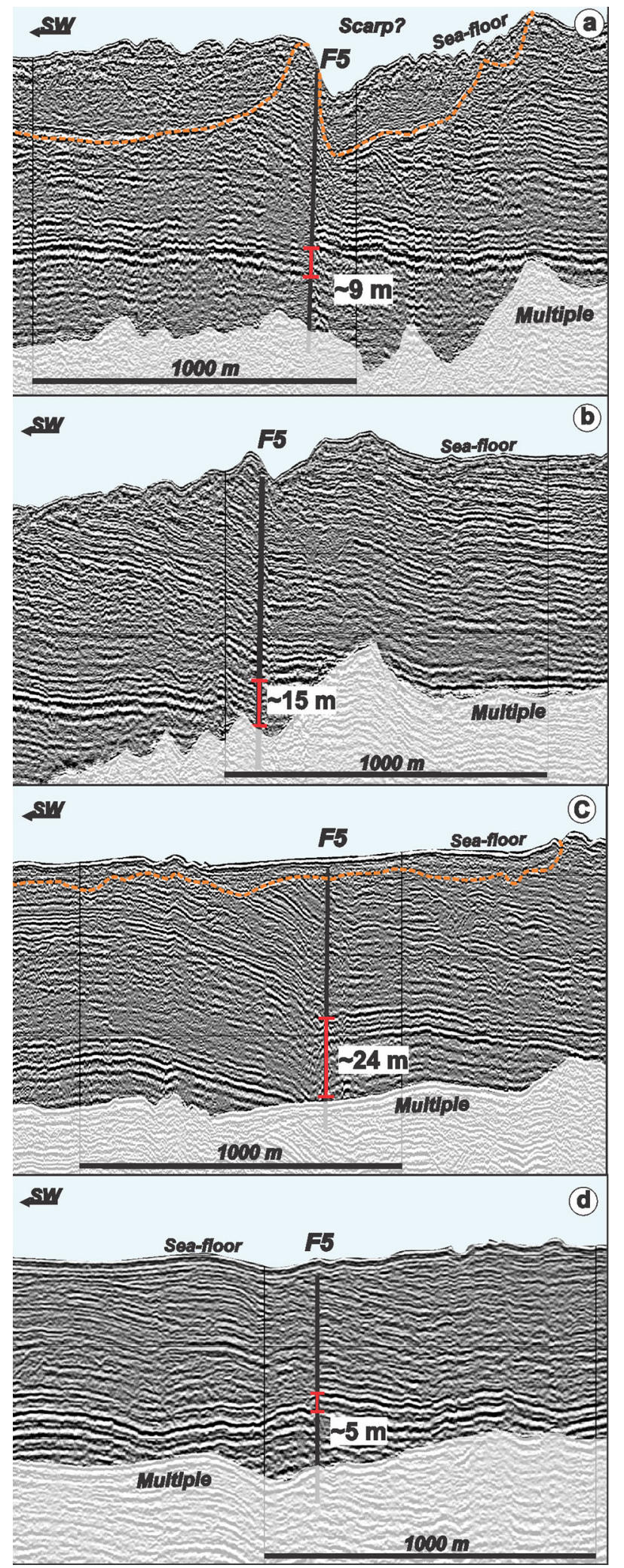

Figure 11. Selected parts of four single-channel seismic-reflection profiles acquired across F5 (location indicated in Fig. 9). Red lines in (a), (b), (c) and (d): offsets induced in the Wealden strata by F5; orange dash line: Quaternary palaeobasins BES. 


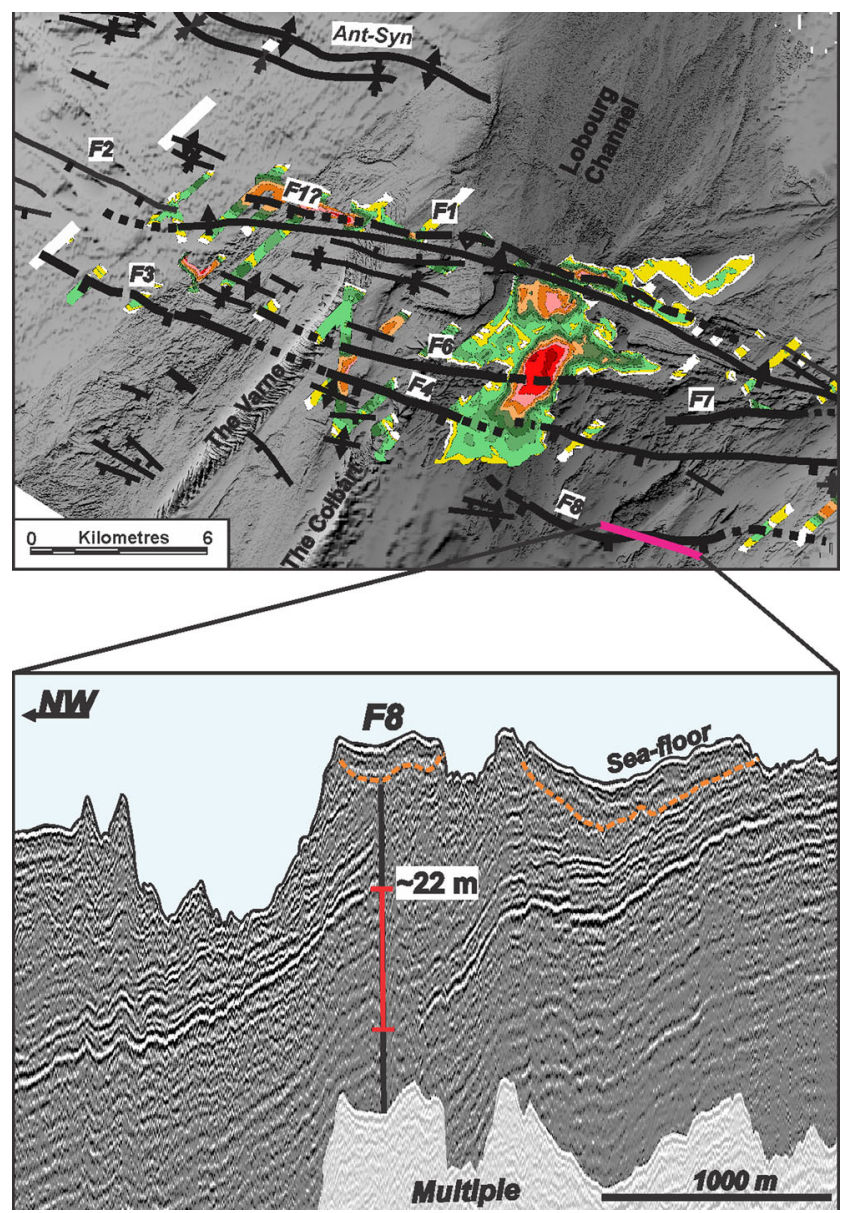

Figure 12. Selected parts of the single-channel seismic-reflection profile acquired across F8. Red line indicates the offset induced in the Wealden strata by F8; orange dash line: Quaternary palaeobasins and palaeochannels BES.

in it appear unaffected by these faults (Fig. 8). F6 seems to be related to a minor step or buried scarp disrupting the southwestern slope of the palaeobasin located underneath the Lobourg channel (Fig. 10b). However, the low amplitude of the reflections infilling this palaeobasin prevented the characterisation of this possible deformation. In any case, it does not seem to extend beyond the thin package of high amplitude reflections corresponding to an erosional surface carved into the sedimentary infill (see Fig. 10b).

The sense and amount of vertical deformation induced by faults F6 and F7 in the Cretaceous bedrock is also uncertain. We were unable to estimate either of these parameters due to the seismic multiple and the strong differences between the seismic facies at either side of the fault planes (Figs 8 and 10a). It is actually possible that this fault system has accommodated significant horizontal offset, which would explain our inability to correlate the seismic reflections across the fault. Indeed, the Greensand ridge (axis of the monocline) appears to have been right-laterally bent about $350 \mathrm{~m}$ where it intersects the inferred continuation of F7 (Fig. 5). Unfortunately, we did not find any other right-laterally deformed bathymetric markers to positively link this bend with activity on the fault.

Finally, F8 is only imaged in one of the single-channel seismicreflection profiles (Fig. 12) and two of the multichannel seismic lines, preventing an accurate analysis of its activity. This nearly W-E trending southwest-dipping fault appears to offset normally the lower Cretaceous and probably upper Jurassic strata by about
$20 \mathrm{~m}$ (Fig. 12). No Quaternary deformation has been observed in the available geophysical data associated with this structure.

Apart from the tectonic structures described above, several other faults and folds are present in our study area deforming the Cretaceous bedrock (see Figs 5-11). We do not describe these structures in detail because they are either of minor importance (e.g. F2) with respect to the ones described above or poorly imaged in the seismic investigation (e.g. F3b). However, these structures are included in the structural and geological maps shown in Figs 5 and 12.

\section{DISCUSSION}

The new bathymetric data gathered for this study have revealed a seafloor morphology strongly influenced by the erosional and sediment-starved conditions presently prevailing in the Dover Strait. Indeed, the geophysical data shows that, apart from some minor and major sandbanks, there has been almost no Holocene deposition in this area. This environment has resulted in very good preservation of the major Late-Quaternary erosional features (e.g. the Lobourg Channel) and a range of the Cretaceous sedimentary formations and older tectonic structures outcropping at the seafloor (see Figs 5-12).

The major Quaternary sediment-filled palaeobasins (i.e. Fosse Dangeard) are located along or in between the main tectonic structures identified in this area. However, even though some of them present possible minor deformations affecting their BES, neither their morphology nor the locations of their depocentres are controlled by the deformations accommodated by the tectonic structures traversing or nearby them (Figs 6,9 and 10). These features were thus formed by erosion as already stated by most of the studies previously performed in this area (e.g. Destombes et al. 1975; Smith 1985; Hamblin et al. 1992; Gupta et al. 2007).

The tectonic structures identified in the Dover Strait are mainly deforming Lower Cretaceous sedimentary formations. The largest deformations are concentrated on the WNW-ESE north-facing monocline and fault F1. These two structures present the same apparent polarity (i.e. F1 reverse offset is in agreement with the monocline folding), suggesting that their associated deformations were produced during a similar tectonic regime. Their proximity and the continuity of the Greensand ridge (which is the surface expression of both the monocline and hanging wall of F1) indicate that these two deformational features are probably different expressions of the same structure. In other words, the monocline is most likely a blind reverse fault system, whose master fault or one of its associated segments may reach the surface in the central part of the strait as F1. The monocline/F1 structure, together with the anticline/syncline system identified to its northeast, thus point to a compressional tectonic episode during which the whole Cretaceous sequence was folded and faulted. This episode most likely corresponds to the tectonic inversion that started in early Palaeogene times (e.g. Mansy et al. 2003).

The offset produced by the monocline/F1 structure in the Cretaceous strata has almost no expression in the seafloor (Fig. 5), indicating that more than $100 \mathrm{~m}$ of bedrock have been eroded from this area since these structures were formed. This has resulted in the exhumation of the Wealden Beds to the south of the north-facing monocline (Figs 8 and 9). Younger Cretaceous formations outcrop only northwestward of this structure. Notably, the Lower Greensand is restricted to the monocline axis in the central part of the strait. This observation disagrees with the bedrock-geological map presently available, which proposed a broader outcrop for the Lower Greensand formation (see Fig. 3). Neither does that bedrock-geological 


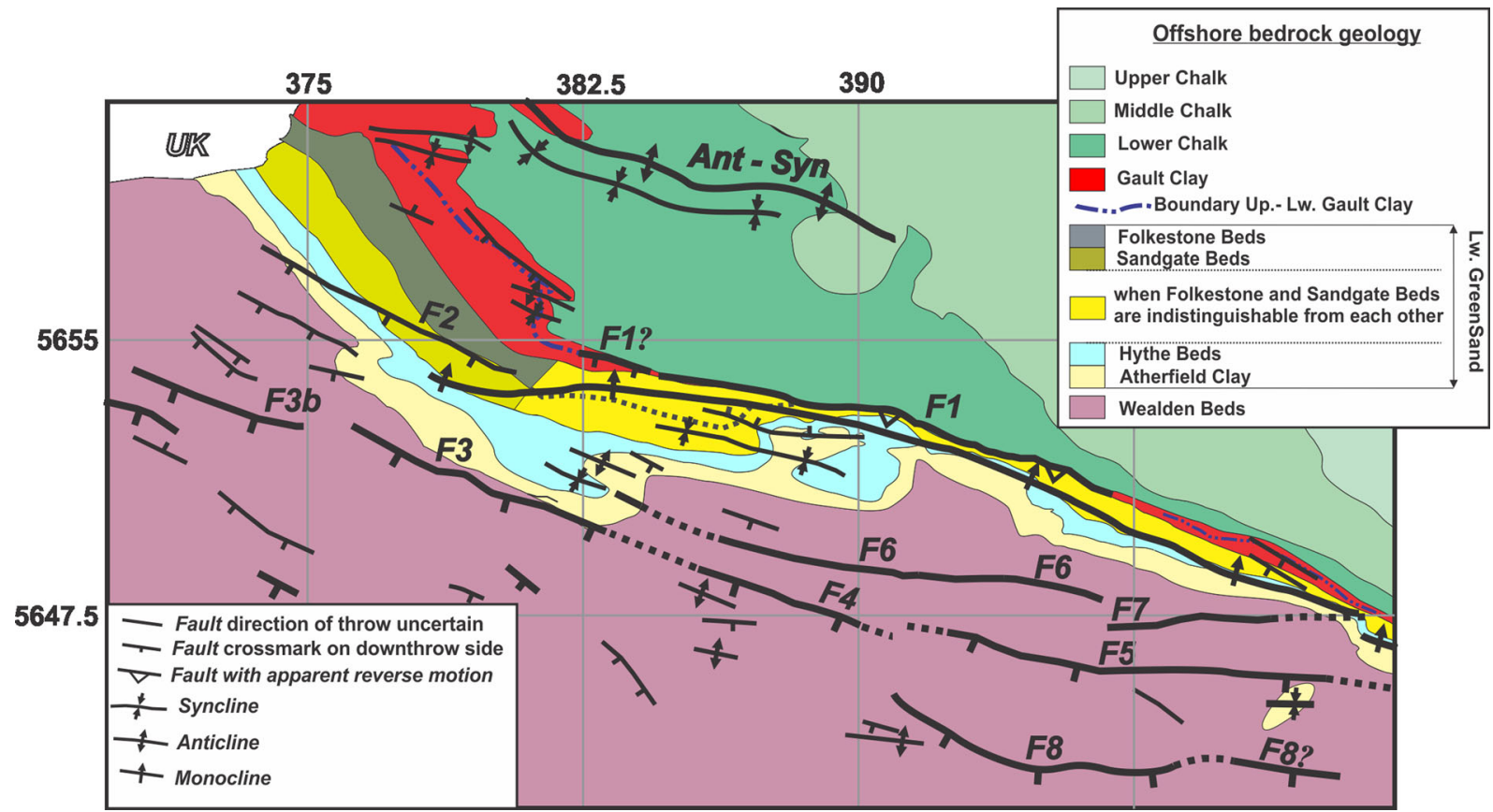

Figure 13. Bedrock geology of the Dover Strait derived from the interpretation of the seismic-reflection and multibeam bathymetric datasets available for this study.

map indicate the significant reverse offset produced by $\mathrm{F} 1$ in the central part of the strait. Fig. 13 shows the new bedrock-geological map derived from our investigation, including the aforementioned observations and the lithology and thickness variations of the Lower Greensand and Gault Clay formations described in Section 4.1.

The compressional deformation produced by the monocline/F1 structure does not seem to have influenced the shape of the Quaternary palaeobasins located in this area. On the contrary, the Quaternary offset associated with the possible northwestern continuation of F1 follows the sense of its dip, resulting in geometries more typical of extensional faults (Fig. 9a). That suggests that the compressional regime ended prior to the formation of the Fosse Dangeard.

Significant deformation of the Lower Cretaceous strata has also been observed along fault systems F3-F4-F5, F6-F7 and F8, most of them associated with apparent normal and/or strike-slip faulting. A characteristic of these faults is the significant lateral variation of their associated offsets and the vertical and horizontal variations of the bending of the strata near their fault planes (see Figs 7, 10 and 11). Similar variations of the offset and seismic-strata geometries have been observed in the central English Channel by Collier et al. (2006). These authors interpreted that as the consequence of the tectonic inversion of initially syn-sedimentary extensional faults combined with the heterogeneous sediment composition and spatial distribution of the Lower Cretaceous continental deposits. This interpretation is consistent with the lateral and vertical variation of the offsets and bending of the strata observed along the system F3-F4-F5. The fact that we do not observe an inversion of the original normal offsets associated with these structures is because they only traverse Wealden and older sedimentary formations in our study area. That is, the reverse deformation produced in the Wealden Beds during the Tertiary tectonic inversion may not have been enough to compensate the significant pre-existing extensional offsets. On the other hand, the monocline/F1 and anticline/syncline systems are deforming much younger sediments (Aptian-Turonian age), which were subjected to the Cretaceous extensional settings during shorter periods of time than the Wealden Beds. Hence, their original normal offsets would have been much smaller and, so, overcompensated by the Tertiary tectonic inversion. This is consistent with the observations of Minguely et al. (2010) and Underhill \& Paterson (1998) in the North Artois shear zone (northeastern France) and the Wessex Basin (Southern England), respectively. Both studies showed several examples of faults that offset the upper and younger sedimentary strata reversely, while the offset in the lower and older strata remains normal.

Alternatively, the particular characteristics of the fault systems F3-F4-F5 and F6-F7 and the apparent change of polarity along F1 could be due to strike-slip deformation. This interpretation would be in good agreement with the high dipping angles of F6 and F7 fault planes and the apparent right-lateral bend of the Greensand ridge observed at its intersection with the possible prolongation of F7 (Fig. 5). The right-lateral offset of the monocline structure would actually imply that this possible strike-slip motion took place following the Tertiary compressional episode. If that was so, it is plausible that the system F3-F4-F5 may also have accommodated some strike-slip deformation following the tectonic inversion. However, the observed up-sequence variations in dip of the seismic-strata near the system F3-F4-F5 fault planes are better explained by the normal-faulting hypothesis.

The limited penetration of the seismic-reflection profiles available for this study prevented imaging the basement and the relationship among the different faults at depth. It is remarkable though that all major structures are located within the gravity anomaly interpreted as the Sangatte Fault (compare Figs 2 and 5), suggesting that they all belong to the same structure: the Sangatte Fault system.

We have not been able to identify the actual source of the AD 1580 or the possible deformation associated with the rupture that caused this earthquake. However, we have identified possible Quaternary fault activity from irregularities, offsets and changes of the dip within the lower sedimentary infill and BES of the Pleistocene palaeobasins (Figs 7-11). Especially notable are the irregular cross-sectional morphologies of some minor palaeobasins located 
along F3 (Fig. 7b) and the apparent $\sim 5 \mathrm{~m}$ vertical offset of one of the palaeobasin BES by the possible northwestern continuation of F1 (Fig. 9a). Nevertheless, neither of these deformations seems to extend above the first erosional surface that truncates the lower layers of the palaeobasins sedimentary infill (see Figs 7b, 9 and $10 \mathrm{~b}$ ). As a matter of fact, these faults have virtually no expression on the seafloor where their paths cross the various Quaternary palaeobasins and palaeochannels. This means that the deformation cumulated since the lower infill was eroded must be below the maximum resolution of the geophysical data, which is $1-3 \mathrm{~m}$ for the seismic-reflection profiles and $1.5 \mathrm{~m}$ for the bathymetric data.

The Dover Strait was exposed to subaerial erosional/depositional settings during the last three major Pleistocene glacial stages (e.g. Gibbard 1995). Consequently, we cannot rule out the possibility that the erosional surfaces that are unaffected by the faults were formed during the last glacial stage $(0.11-0.012 \mathrm{Ma})$. This is also true for the apparent lack of deformation in the seafloor. Indeed, any minor deformations could have been washed out during the last marine low stand; especially those affecting the Lobourg Channel, which may have confined a significant river during the last glacial maximum (0.03-0.025 Ma) (e.g. Gibbard 1995). Therefore, with the data presently available we can only state that the Sangatte Fault system has produced deformations less than 1-3 $\mathrm{m}$ since the Holocene started. The cumulated offset since the Fosse Dangeard was formed in Middle Pleistocene appears to be of $\sim 5 \mathrm{~m}$. However, this could be smaller, as the buried scarp on which we measured this offset could have been caused or exaggerated by the erosional process that originated the Fosse Dangeard.

In summary, earthquakes of magnitudes equal to or higher than 6 seem to have been very rare in this area since Middle Pleistocene. This makes the AD 1580 an exceptional event. As a matter of fact, assuming that the cumulated deformation accommodated by the Sangatte Fault system during the Holocene epoch is just below the maximal resolution of the geophysical data $(1.5 \mathrm{~m})$, we can estimate by applying the equations of Wells \& Coppersmith (1994) that this deformation would correspond either to the occurrence of a single $M_{\mathrm{w}} \sim 7.0$ earthquake produced by a fault with an average length of $\sim 40 \mathrm{~km}$, or to very few earthquakes with magnitudes equal to or lower than 6.0 on shorter faults. More importantly, these estimations suggest that none of the earthquakes produced by the Sangatte Fault system since that epoch has exceeded a maximum magnitude of 7.0 , which is consistent with the length of the individual structures composing it.

\section{CONCLUSIONS}

This study demonstrates the presence of a more complex yet continuous fault-and-fold system traversing the Dover Strait/Pas-deCalais than previously published. This fault-and-fold system offsets the Cretaceous sediment strata enough to influence the bedrock geology outcropping at the seabed. The system is composed of several major and minor tectonic structures accommodating either compressional deformation or deformations more typical of extensional and/or strike-slip regimes. The comparison between these different styles of deformation and the known regional tectonic history suggests that the compressional structures were formed during the Tertiary compressional phase. Apparent normal deformations would be then more likely linked to the Jurassic-Cretaceous extensional phase and/or to a strike-slip episode that took place after the Tertiary tectonic inversion. The latter seems to be the case for the system F6-F7, which may significantly offset right-laterally the compressional monocline structure. However, we have not been able to determine when this possible strike-slip deformation started or whether it has been ongoing during the Quaternary.

The possible Quaternary tectonic activity of the main structures identified in this study seems to have been very low in recent times. Whilst the lack of recent deformation in the bathymetry could be explained by the strong erosional tidal conditions in the Dover Strait, the fact that we do not see it in the upper layers of the palaeobasins sedimentary infill suggests that, if this exists, it must be below the resolution (1-3 m) of the single-channel seismic-reflection data. The cumulated deformation accommodated since Middle Pleistocene by this fault system may actually be lower than $5 \mathrm{~m}$. Therefore, if the Sangatte Fault system has been active during the late-Quaternary period, the recurrence interval of large earthquakes must have been very long. Thus, earthquakes similar to the AD 1580 event have been rare in this area. Earthquakes of greater magnitudes seem to have been even rarer or non-existent. Nonetheless, the size of the structures identified in this study suggests that they could potentially rupture in earthquakes with magnitudes up to 7 .

In conclusion, this study supports the episodic character of the seismic activity typical of tectonic structures located in plate interiors. These structures present 'short' periods of activity followed by long periods of seismic quiescence that may correspond with the activity of nearby regional structures. This 'migration' of the seismicity is well observed in northwestern Europe, where most of the known moderate and large historical earthquakes have occurred at different locations (Camelbeeck et al. 2007).

\section{ACKNOWLEDGEMENTS}

We would like to thank Koen De Rycker for the great job he did during the data acquisition. Many thanks also to Tine Missiaen, Rindert Janssens, Matthias Baeye, Philipp Kempf, Geoffroy Van Kriekinge, Pierre Legrand, Alexander Comeyne, Naomi De Roeck, Sophie Van de Putte and Billie Heene for their assistance during data acquisition. Thanks go as well to NIOZ for renting us the multichannel acquisition equipment, and in particular to Hendrik De Haas and Leon Michael Wuis for their hard work during the acquisition of the data. We would also like to thank the Captains and Crews of the RV Belgica and R/V INSU 'Côtes de la Manche' for their excellent work during the geophysical campaigns. Ship Time on the RV Belgica was provided by BELSPO and RBINS-OD Nature, and managed by MUMM (www.mumm.ac.be). Le Service Hydrographique et Océanographique de la Marine (SHOM) provided single-beam data for French waters (Contract No. 205/2011) and the UK Hydrographic Office and UK Maritime and Coastguard Agency provided single and multibeam data for UK waters.

\section{REFERENCES}

Arthur, J.C.R., Phillips, G. \& McCormick, C.R., 1997. High definition seismic for Channel Tunnel marine route, in Modern Geophysics in Engineering Geology, Vol. 12, pp. 327-334, eds McCann, D.M., Eddleston, M., Fenning, P.J. \& Reeves, G.M., Geological Society Engineering Geology, Special Publication.

Bergerat, F. \& Vandycke, S., 1994. Paleostress analysis and geodynamical implications of Cretaceous-Tertiary faulting in Kent and the Boulonnais, J. Geol. Soc., 151, 439-448.

Camelbeeck, T. et al., 2007. Relevance of active faulting and seismicity studies to assessments of long-term earthquake activity and maximum magnitude in intraplate northwest Europe, between the Lower Rhine Embayment and the North Sea, Geol. Soc. Am., 425, 193-224. 
Chadwick, R.A., Evans, D.J. \& Holliday, D.W., 1993. The Maryport fault: the post-Caledonian tectonic history of southern Britain in microcosm, J. Geol. Soc., 150, 247-250.

Clark, C.D., Gibbard, P.L. \& Rose, J., 2004. Pleistocene glacial limits in England, Scotland and Wales, in Developments in Quaternary Sciences, pp. 47-82, eds Ehlers, J. \& Gibbard, P.L., Elsevier.

Colbeaux, J.P., Somme, J. \& Tuffreau, A., 1981. Tectonique quaternaire dans le Nord de la France: l'apport du gisement paléolithique de Biache-SaintVaast, Bulletin de l'Association française pour l'étude du quaternaire, 18, 183-192.

Collier, J.S, Gupta, S., Potter, G. \& Palmer-Felgate, A., 2006. Using bathymetry to identify basin inversion structures on the English Channel shelf, Geology, 34, 1001-1004.

De Béthune, P. \& Bouckaert, L., 1968. Geological Map of Belgium and Neighbouring Countries: Brussels, Geological survey of Belgium Miscellaneous Geological Maps, scale 1:2 000 000, 1 sheet.

Destombes, J.P., Shephard-Thorn, E.R., Redding, J.H. \& Morzadeckerfourn, M.T., 1975. Buried valley system in the Strait of Dover, Phil. Trans. R. Soc. A.: Math. Phys. Eng. Sci., 279, 243-256.

Everaerts, M. \& Mansy, J.-L., 2001. Le filtrage des anomalies gravimétriques; une clé pour la compréhension des structures tectoniques du Boulonnais et de l'Artois (France), Bulletin de la Société Géologique de France, 172, 267-274.

Froidevaux, C., Paquin, C. \& Souriau, M., 1980. Tectonic stresses in France: in situ Measurements with a flat jack, J. geophys. Res., 85, 6342-6346.

Gibbard, P.L., 1995. The formation of the Strait of Dover, Geol. Soc., Lond., Spec. Publ., 96, 15-26.

Grünthal, G., Wahlström, R. \& Stromeyer, D., 2009. The unified catalogue of earthquakes in central, northern, and northwestern Europe (CENEC) updated and expanded to the last millennium, J. Seismol., 13, 517-541.

Gupta, S., Collier, J., Palmer-Felgate, A. \& Potter, G., 2007. Catastrophic flooding origin of shelf valley systems in the English Channel, Nature, 448, 342-346.

Hamblin, R.J.O., Crosby, A., Balson, P.S., Jones, S.M., Chadwick, R.A., Penn, I.E. \& Athur, M.J., 1992. United Kingdom offshore regional report: the geology of the English Channel. HMSO for the British Geological Survey, London.

Hopson, P.M., Wilkinson, I.P. \& Woods, M.A., 2010. A stratigraphical framework for the Lower Cretaceous of England. Research Report RR/08/03. British Geological Survey, Keyworth

James, J.W.C. et al., 2002. GEOSYNTH: A synthesis of the geology and sediments of the Dover Strait and its hinterland. CR/02/078, CDROM, British Geological Survey.

Lericolais, G., Auffret, J.-P. \& Bourillet, J.-F., 2003. The Quaternary Channel River: seismic stratigraphy of its palaeo-valleys and deeps, J. Quater. Sci., 18, 245-260

Mansy, J.-L., Manby, G.M., Averbuch, O., Everaerts, M., Bergerat, F., Van Vliet-Lanoe, B., Lamarche, J. \& Vandycke, S., 2003. Dynamics and inversion of the Mesozoic Basin of the Weald-Boulonnais area: role of basement reactivation, Tectonophysics, 373, 161-179.

Mellet, C., Hodgson, M., Plater, A., Mauz, B., Selby, I. \& Lang, A., 2013. Denudation of the continental shelf between Britain and France at the glacial-interglacial timescale, Geomorphology, 203, 79-96.

Melville, C.P., Levret, A., Alexandre, P., Lambert, J. \& Vogt, J., 1996. Historical seismicity of the Strait of Dover/Pas de Calais, Terra Nova, 8, 626-647.

Minguely, B., Averbuch, O., Patin, M., Rolin, D., Hanot, F. \& Bergerat, F., 2010. Inversion tectonics at the northern margin of the Paris basin (northern France): new evidence from seismic profiles and boreholes interpolation in the Artois area, Bulletin de la Société Géologique de France, 181, 429-442.

Mortimore, R.N., 2011. A chalk revolution: what have we done to the Chalk of England?, in Proceedings of the Geologists' Association, Vol. 122, pp. 232-297.

Musson, R.M.W., 2004. A critical history of British earthquakes, Ann. Geophys., 47, 597-609.
Neilson, G., Musson, R.M.W. \& Burton, P.W., 1984. The London Earthquake of 1580, April 6, Eng. Geol., 20, 113-141.

Ottemöller, L., Baptie, B. \& Smith, N.J.P., 2009. Source Parameters for the 28 April $2007 \mathrm{Mw}$ 4.0 Earthquake in Folkestone, United Kingdom, Bull. geol. Soc. Am., 99, 1853-1867.

Owen, H.G., 1975. The stratigraphy of the Gault and Upper Greensand of the Weald, in Proceedings of the Geologists' Association, Vol. 86, pp. 475-498.

Radley, J.D. \& Allen, P., 2012. The Wealden (non-marine Lower Cretaceous) of the Weald Sub-basin, southern England, in Proceedings of the Geologists' Association, Vol. 123, pp. 245-318.

Reynaud, J-Y., Tessier, B., Auffret, J-P., Berné, S., De Batist, M., Marsset, T. \& Walker, P., 2003. The offshore Quaternary sediment bodies of the English Channel and its Western approaches, J. Quater. Sci., 18, 361-371.

Ruffell, A.H. \& Wach, G.D., 1991. Sequence stratigraphic analysis of the Aptian-Albian Lower Greensand in southern England, Mar. Petrol. Geol., 8, 341-353.

Smith, A.J., 1985. A catastrophic origin for the palaeovalley system of the eastern English Channel, Mar. Geol., 64, 65-75.

Stein, S. \& Mazzotti, S., 2007. Continental Intraplate Earthquakes: Science, Hazard and Policy Issues, Geol. Soc. Am., Spec. Paper, 425, 402.

Toucanne, S. et al., 2009. A 1.2 Ma record of glaciation and fluvial discharge from the West European Atlantic margin, Quarter. Sci. Rev., 28, 2974 2981.

Underhill, J.R. \& Paterson, S., 1998. Genesis of tectonic inversion structures: seismic evidence for the development of key structures along the PurbeckIsle of Wight disturbance, J. Geol. Soc., Lond., 155, 975-992.

Vandycke, S., Bergerat, F. \& Dupuis, C., 1988. Paléo-contraintes à la limite Crétacé-Tertiaire dans le Bassin de Mons (Belgique). Implications cinématiques. Relations avec la zone de Cisaillement Nord-Artois, C. R. Académie de Sciences de Paris, 307(II), 303-309

Van Vliet-Lanoë, B., Mansy, J.L., Margerel, J.P., Vidier, J.P., Lamarche, J. \& Everaerts, M., 1998. Le Pas de Calais un détroit cénozoïque à ouverture multiple, C. R. Académie de Sciences de Paris, 326(II), 729-736.

Van Vliet-Lanoë, B., Laurent, M., Bahain, J.L., Balescu, S., Falguères, C., Field, M., Hallégouët, B. \& Keen, D.H., 2000. Middle Pleistocene raised beach anomalies in the English Channel: regional and global stratigraphic implications, J. Geodyn., 29, 15-41.

Van Vliet-Lanoë, B. et al., 2002a. Cenozoic evolution of the Channel and southern North Sea areas (Western Europe). The neotectonic control on sedimentation and rivers, in Contributions to the Geology of Belgium and Northwest Europe: Proceedings of the First Geologica Belgica International Meeting, Leuven, Vol. 12, pp. 21-24, eds Degryse, P. \& Sintubin, M., 11-15 September 2002. Aardkundige Mededelingen.

Van Vliet-Lanoë, B. et al., 2002b. Palaeogeographic evolution of Northwestern Europe during the upper Cenozoic, Geodiversitas, 24, 511541.

Van Vliet-Lanoë, B., Mansy, J.L., Henriet, J.-P., Laurent, M. \& Vidier, J.P., 2004. Une inversion tectonique cénozoïque par étapes : le Pas-de-Calais, Bulletin Société géologique Français, 175-2, 175-195.

Warren, S.T. \& Harris, C.S., 1996. An interpretation of the structural geology, in Engineering Geology of the Channel Tunnel, pp. 421-435, eds Harris, C.S., Hart, M.B., Varley, P.M. \& Warren, C.D., Thomas Telford Ltd.

Wells, D.L. \& Coppersmith, K.J., 1994. New empirical relationships among magnitude, rupture length, rupture width, rupture area, and surface displacement, Bull. geol. Soc. Am., 84, 974-1002.

Woods, M.A., Wilkinson, P. \& Hopson, P.M., 1995. The stratigraphy of the Gault Formation (Middle and Upper Albian) in the BGS Ariesey Borehole, Bedfordshire, in Proceedings of the Geologists' Association, Vol. 106, pp. 271-280.

Zoback, M.D. \& Grollimund, B., 2001. Impact of deglaciation on presentday intraplate seismicity in eastern North America and Western Europe, C. R. Académie de Sciences de Paris/Earth planet. Sci., 333, $23-33$. 


\section{SUPPORTING INFORMATION}

Additional Supporting Information may be found in the online version of this paper:

Table S1. Summary of the available bathymetric datasets, indicating the extent and the resolution of the DTMs. MBES: multibeam echo soundings; SBES: single-beam echo soundings. (http:/gji.oxfordjournals.org/lookup/suppl/doi:10.1093/gji/ggv041 /-/DC1).

Please note: Oxford University Press is not responsible for the content or functionality of any supporting materials supplied by the authors. Any queries (other than missing material) should be directed to the corresponding author for the article. 